\title{
Hydrolysis of Hemicellulosic Feed Stocks by Enterobacter Species in the Production of Bio-Ethanol
}

\author{
C.T. Puttaswamy ${ }^{1 *}$, L. Udaya Simha ${ }^{2}$, S. Manjappa ${ }^{3}$ and C.S. Vinod Kumar ${ }^{4}$ \\ ${ }^{1}$ Department of Chemical Engineering, BMS College of Engineering, \\ Bangalore, Karnataka, India \\ ${ }^{2}$ Department of Civil Engineering, BMS College of Engineering, Bangalore, Karnataka, India \\ ${ }^{3}$ Research and Development, Sahyadri College of Engineering \& Management, \\ Mangalore, Karnataka, India \\ ${ }^{4}$ Department of Microbiology, S. S. Institute of Medical Science and Research Centre, \\ Davangere, Karnataka, India \\ *Corresponding author email id: puttaswamyct.che@bmsce.ac.in
}

\begin{tabular}{|c|c|}
\hline & A B S T R A C T \\
\hline Keywords & \multirow{8}{*}{$\begin{array}{l}\text { Biomass have gained much attention as a new sustainable energy source alternative } \\
\text { to petroleum-based fuels. The second-generation bioethanol from lignocellulosic } \\
\text { materials became a promising approach since the lingo-celluloses are not directly } \\
\text { in competition with food sources. The present study focused on screening the } \\
\text { Enterobacter species isolated from environment for hemicellulytic activity on } \\
\text { beech wood, hard wood, bagasse and wheat straw. The optimization of pH, } \\
\text { Temperature, Ratio of feedstock to water and feedstock to microbe concentration } \\
\text { was analyzed. Optimum temperature, } \mathrm{pH} \text { and substrate concentration for } \\
\text { hydrolysis for feed stocks was found to be } 32^{\circ} \mathrm{C}, 7.4 \mathrm{pH}, 8.0 \mathrm{~g} \text { and } 250 \mathrm{ml} \\
\text { feedstock to water. An ethanol yield of } 2.3 \% \mathrm{v} / \mathrm{v} \text { for beech wood, } 2.1 \% \mathrm{v} / \mathrm{v} \text { for hard } \\
\text { wood, } 1.92 \% \mathrm{v} / \mathrm{v} \text { for bagasse \& } 1.7 \% \mathrm{v} / \mathrm{v} \text { for wheat straw was obtained for } 8.0 \% \text { of } \\
\text { the feedstock. }\end{array}$} \\
\hline Hydrolysis, & \\
\hline $\begin{array}{l}\text { Hemicellulose, } \\
\text { Enterobacter }\end{array}$ & \\
\hline $\begin{array}{l}\text { species, } \\
\text { Ethanol. }\end{array}$ & \\
\hline & \\
\hline Article Info & \\
\hline & \\
\hline $\begin{array}{l}\text { Available Online: } \\
10 \text { July } 2016\end{array}$ & \\
\hline
\end{tabular}

\section{Introduction}

In recent years, environmental concerns related to increased average temperatures and rising atmospheric carbon dioxide levels have prompted much debate on the use of fossil fuels. About $25 \%$ of global carbon dioxide emissions come from the transportation sector, with three quarters of that being attributed to road transport (IEA, 2009) (IEA, 2009). Additionally, there is a striking difference in the use of vehicles around the world.
The expected increase in global population to an estimated 8.3 billion by 2030 (Arundel, 2009), means energy needs for transportation could double by 2050 (IEA, 2009). The need for a more sustainable and renewable fuel is thus evident and imperative.

There is a variety of potential biofuels that could be produced and used to replace petroleum based fuels, including bioethanol, 
biogas, biodiesel and bio-butanol. Each fuel clearly has its own virtues and disadvantages and a combination of them will likely be needed in order to efficiently replace oil.

Almost all fuel ethanol today is produced from sugar (sugar cane) or starch (mainly corn), through '1st generation or conventional' bioethanol processes. The production of conventional bioethanol has been increasingly questioned for competing for agricultural land with food and feed production. Therefore, the issue is no longer only how to replace fossil fuels, but how to do this in a sustainable manner (Goldemberg, 2006). This has shifted focus away from using conventional agricultural raw materials to using lignocellulosic biomass, also known as '2nd generation' or advanced biofuels.

There are two processes options envisaged to release fermentable sugars from lignocellulosic feedstocks of biomass. One approach is acid or alkali hydrolysis to break down the complex structure long chain monosaccharide's or polysaccharides into simple sugars. The second or an alternative method is enzymatic hydrolysis with pretreated process to reduce the size of the feedstock which is accessible for hydrolysis, after employing the pretreated lignocellulosic feedstock biomass to fermentable sugars, finally the microbial fermentation to produce bioethanol and carbon dioxide (Borjesson, 2009). The bottleneck for the use of lignocellulosic biomass as raw material for the production of biofuels is the lack of technology for the efficient conversion of biomass. The limiting factor is the low cost processing technologies for the conversion of this feedstock to biofuel does not exist as on date. Of all the steps described earlier, it is the biomass hydrolysis step which requires special attention. Any process which has an efficient and low cost hydrolysis step will emerge as the best process for the conversion of biomass to biofuel (Borjesson, 2009). Significant research is going on for finding the efficient and low cost hydrolysis route for the lignocellulosic feedstock conversion. This research work is an attempt on similar lines to find an innovative method of hydrolysis of hemicellulose biomass using bacteria obtained from the environment.

\section{Materials and Methods}

In the present study, four different lignocellulosic biomaterials from which the hemicellulose can be extracted have been considered and utilized. They are industrial hardwood effluent, wheat straw, sugarcane bagasse and beech wood as Xylan. The hemicellulose was obtained by pretreatment and by alkali hydrolysis.

\section{Isolation of bacteria}

Soil samples were collected from various places of Karnataka during the monsoon season. The samples were collected in sterile polyethylene bags and bottles, which were preserved in the refrigerator for further investigation. Standard microbiological methods were followed for the purpose of isolation (Brown, 1985). One $\mathrm{ml}$ of the desired dilution was transferred aseptically into MacConkey's agar, blood agar and Nutrient agar for the isolation of bacteria. Plates were incubated for 24- $48 \mathrm{hrs}$ for bacterial fungal growth. The isolates thus obtained were characterized.

\section{Hemicellulolytic (Xylanolytic) enzyme assay}

Relatively little attention has been given to qualitative assays for Xylan utilization and only a few assay procedures have been 
described. Actively growing culture was used to inoculate each assay medium and incubated for 24-72hrs for optimization study (Jørgensen et al., 2003).

\section{Dye staining of Xylan agar}

The Xylanolysis basal medium was prepared by incorporating with $8 \% \mathrm{w} / \mathrm{v}$ hemicellulose obtained from the feedstocks and $1.6 \% \mathrm{w} / \mathrm{v}$ of agar and autoclaved. The sterile media were aseptically transferred to the sterile petri dishes and inoculated with the test organism individually. The plates were then incubated at room temperature for $48 \mathrm{~h}$ for bacteria. The media after the growth was flooded with iodine stain $(0.25 \% \mathrm{w} / \mathrm{v}$ aqueous $\mathrm{I} 2$ and $\mathrm{KI}$ ) for $5 \mathrm{~min}$, the stain was removed and the agar surface washed with distilled water. Xylan degradation around the colonies appeared as yellow-opaque area against a blue/reddish purple color for undegraded (Biely, 1985; Cai et al., 1995).

\section{Experimentation}

The behaviour of variables like temperature, $\mathrm{pH}$ and substrate on hydrolysis was investigated through systematic experimentation.

\section{Optimum variable conditions for hydrolysis}

The effect of temperature on hydrolysis of hemicellulose was determined by incubating the reaction mixture at different temperature ranging from 27 to $40^{\circ} \mathrm{C}$. The behaviour of $\mathrm{pH}$ was determined by adjusting the $\mathrm{pH}$ of the reaction mixture from 1 to 10 . The substrate concentration on hydrolysis was determined by preparing substrate suspensions 1 to $10 \%$ as suggested by some of the investigators (Sluiter 2008, Templeton, 2008, Surender 2010). Determination of total sugars, pentose sugars and enzyme activities was analysed by liquid chromatography mass spectrometry (HYM BROTHER ANLYTICAL SOLUTIONS P. LTD) methods. All the required standard chemicals and sugar standards are procured from Himedia.

\section{Statistics}

All the tests were laid in completely randomized design and each treatment was tested for five times. ANOVA analyses were carried out with Assistat 7.5 beta.

\section{Results and Discussion}

\section{Estimation of Enzymes}

The total enzyme activities of Enterobacter species for beech wood, hard wood, bagasse and wheat straw is depicted in Table 1 and Fig. 1. Hemi-cellulase is an inducible enzyme and its production increases with increase in bacterial biomass over the incubation period and as the sugars in the substrate diminished, the production of the enzyme decreases. Enterobacter species showed highest enzyme activity for beech wood $(94.7 \mathrm{IU} / \mathrm{ml})$ followed by hardwood (92.4 IU/ml), bagasse (90.43 IU/ml) and wheat straw $(89.32 \mathrm{IU} / \mathrm{ml})$. The highest concentration of enzymes produced in 48 hours of incubation and further starts decreasing.

\section{Substrate/ feedstock concentration}

The different concentration of feedstocks was inoculated with the predetermined fixed volume of the bacteria and the mean sugar concentration was recorded. The effect is shown in Table 2 and Fig. 2.

It can be observed that for $2 \%$ of beech wood, $\quad 49.28 \mathrm{mg} / \mathrm{ml}$ mean sugar 
concentration were measured. Similarly for hard wood $40.46 \mathrm{mg} / \mathrm{ml}$ mean sugar concentration was measured and for 37.30 $46 \mathrm{mg} / \mathrm{ml}$ for bagasse and $27.7246 \mathrm{mg} / \mathrm{ml}$ for wheat straw.

For the feedstock of concentration 6\%, Highest mean sugar concentration of 738.83 $\mathrm{mg} / \mathrm{ml}$ for beech wood, $698.05 \mathrm{mg} / \mathrm{ml}$ for hardwood, $564.27 \mathrm{mg} / \mathrm{ml}$ for bagasse and $428.73 \mathrm{mg} / \mathrm{ml}$ for wheat straw.

For the feedstock of concentration $8 \%$, Highest mean sugar concentration of $1296.37 \mathrm{mg} / \mathrm{ml}$ for beech wood, 1139.37 $\mathrm{mg} / \mathrm{ml}$ for hardwood, $1070.70 \mathrm{mg} / \mathrm{ml}$ for bagasse and $948.03 \mathrm{mg} / \mathrm{ml}$ for wheat straw.

At the feedstock concentration of $10 \%$ the mean sugar concentration started decreasing; highest mean sugar concentration of 520.70 $\mathrm{mg} / \mathrm{ml}$ for beech wood, $448.05 \mathrm{mg} / \mathrm{ml}$ for hardwood, $367.04 \mathrm{mg} / \mathrm{ml}$ for bagasse and $312.75 \mathrm{mg} / \mathrm{ml}$ for wheat straw.

The optimum concentration of substrate that could be easily hydrolyzed by Enterobacter species is $8 \%$, beyond that bacteria was unable to efficiently degrade the hemicellulose of the selected feedstock. The effect of hydrolysis by Enterobacterspp on substrate concentration sugar concentration for beech wood, hard wood effluent, Bagasse and wheat steraw are presented table 2 and fig. 2

\section{Temperature}

The effect of temperature on hydrolysis of hemicellulose by Enterobacter species is shown in the Figure 3 and Table 3.

At $20^{\circ} \mathrm{C}$ mean sugar concentration obtained was $32.5 \mu \mathrm{g} / \mathrm{ml}$ for beech wood, $29.7 \mu \mathrm{g} / \mathrm{ml}$ for hardwood, $22.4 \mu \mathrm{g} / \mathrm{ml}$ for bagasse and $19.0 \mu \mathrm{g} / \mathrm{ml}$ for wheat straw.
At $30^{\circ} \mathrm{C}$ mean sugar concentration obtained was $735.5 \mu \mathrm{g} / \mathrm{ml}$ for beech wood, $700.4 \mu \mathrm{g} / \mathrm{ml}$ for hardwood, $563.0 \mu \mathrm{g} / \mathrm{ml}$ for bagasse and $522.4 \mu \mathrm{g} / \mathrm{ml}$ for wheat straw.

At $32^{\circ} \mathrm{C}$ mean sugar concentrations obtained was $1298.4 \mu \mathrm{g} / \mathrm{ml}$ for beech wood, $1130.1 \mu \mathrm{g} / \mathrm{ml}$ for hardwood, $1082.0 \mu \mathrm{g} / \mathrm{ml}$ for bagasse and $950.4 \mu \mathrm{g} / \mathrm{ml}$ for wheat straw.

SAt $34^{\circ} \mathrm{C}$ mean sugar concentration obtained was $769.8 \mu \mathrm{g} / \mathrm{ml}$ for beech wood, $692.2 \mu \mathrm{g} / \mathrm{ml}$ for hardwood, $597.1 \mu \mathrm{g} / \mathrm{ml}$ for bagasse and $439.8 \mu \mathrm{g} / \mathrm{ml}$ for wheat straw.

At $38^{\circ} \mathrm{C}$ mean sugar concentrations was very low, indicating the temperature is not optimum for the growth of the bacteria and the hydrolysis of the hemicellulose. The mean sugar level estimated at $38^{\circ} \mathrm{C}$ was $102.2 \mu \mathrm{g} / \mathrm{ml}$ for beech wood, $86.4 \mu \mathrm{g} / \mathrm{ml}$ for hardwood, $55.0 \mu \mathrm{g} / \mathrm{ml}$ for bagasse and $32.0 \mu \mathrm{g} / \mathrm{ml}$ for wheat straw.

Hence the optimum temperature for Enterobacter species for the hydrolysis of hemicellulose from different feedstock is $32^{\circ} \mathrm{C}$.

\section{Effect of pH}

Effect of $\mathrm{pH}$ on bacteria for hydrolysis of hemicellulose from different feedstocks is shown in the figure 4 and tables 4 . The sugars were not detected in the $\mathrm{pH}$ of 1-4 and 11-14. The bacteria could not be cultured at the $\mathrm{pH}$ below 4 and above 11 . The hydrolysis of hemicellulose increased from $\mathrm{pH} 5$ and reached highest at the $\mathrm{pH} 7.4$ and gradually decreased at the $\mathrm{pH} 7.4$ till 10.

At $\mathrm{pH} 7.0$, at temperature $32^{\circ} \mathrm{C}$ mean sugar concentration obtained was $847.4 \mu \mathrm{g} / \mathrm{ml}$ for beech wood, $598.4 \mu \mathrm{g} / \mathrm{ml}$ for hardwood, $455.9 \mu \mathrm{g} / \mathrm{ml}$ for bagasse and $309.5 \mu \mathrm{g} / \mathrm{ml}$ for wheat straw. At $\mathrm{pH} 7.4$, mean sugar 
concentration obtained was $1773.7 \mu \mathrm{g} / \mathrm{ml}$ for beech wood, $1355.0 \mu \mathrm{g} / \mathrm{ml}$ for hardwood, $1009.7 \mu \mathrm{g} / \mathrm{ml}$ for bagasse and $928.3 \mu \mathrm{g} / \mathrm{ml}$ for wheat straw.
At $\mathrm{pH} 8$, mean sugar concentration obtained was $948.3 \mu \mathrm{g} / \mathrm{ml}$ for beech wood, 876.3 $\mu \mathrm{g} / \mathrm{ml}$ for hardwood, $648.3 \mu \mathrm{g} / \mathrm{ml}$ for bagasse and $608.7 \mu \mathrm{g} / \mathrm{ml}$ for wheat straw.

Table.1 Enzyme activity ( $\mu$ mole/ml) of Enterobacter spp for different feed stocks

\begin{tabular}{|r|r|r|r|r|}
\hline $\begin{array}{r}\text { Time in } \\
\text { Hours }\end{array}$ & \multicolumn{1}{l|}{$\begin{array}{l}\text { Beech } \\
\text { wood }\end{array}$} & \multicolumn{1}{l|}{$\begin{array}{l}\text { Hard } \\
\text { wood }\end{array}$} & \multicolumn{2}{l|}{$\begin{array}{l}\text { Wheat } \\
\text { Bagasse }\end{array}$} \\
\hline & \multicolumn{2}{|c|}{ Enzyme activity $\mu$ mole/ml or IU } \\
\hline 4 & 0.89 & 0.71 & 0.64 & 0.56 \\
\hline 8 & 2.7 & 1.95 & 1.56 & 1.32 \\
\hline 12 & 9.4 & 7.63 & 6.37 & 6.03 \\
\hline 16 & 20.0 & 20 & 16.83 & 15.22 \\
\hline 20 & 30.39 & 29.92 & 24.75 & 22.84 \\
\hline 24 & 39.08 & 37.24 & 35.59 & 35.06 \\
\hline 28 & 50.89 & 43.85 & 40.61 & 42.78 \\
\hline 32 & 65.32 & 58.56 & 53.4 & 52.83 \\
\hline 36 & 78.05 & 76.32 & 72.93 & 71.29 \\
\hline 40 & 85.44 & 82.53 & 81.62 & 80.03 \\
\hline 44 & 90.31 & 89.036 & 85.71 & 83.52 \\
\hline 48 & 94.702 & 92.365 & 90.43 & 89.32 \\
\hline 49 & 90.09 & 87.701 & 83.79 & 80.9 \\
\hline 50 & 85.21 & 82.025 & 77.26 & 70.98 \\
\hline
\end{tabular}

Table.2 Effect of Hydrolysis by Enterobacter spp on substrate concentration

\begin{tabular}{|c|r|r|r|r|}
\hline & \multicolumn{1}{|l|}{$\begin{array}{l}\text { Beech } \\
\text { wood }\end{array}$} & Hard wood & \multicolumn{1}{l|}{ Bagasse } & \multicolumn{1}{l|}{$\begin{array}{l}\text { Wheat } \\
\text { Straw }\end{array}$} \\
\cline { 2 - 5 } Substrate $(\mathrm{g})$ & \multicolumn{4}{|l|}{ Pentose sugar concentration in $\mu \mathrm{g} / \mathrm{mL}$} \\
\hline 1 & 30.270 & 26.824 & 21.279 & 14.209 \\
\hline 2 & 49.283 & 40.468 & 37.306 & 27.728 \\
\hline 3 & 190.732 & 170.000 & 120.052 & 48.000 \\
\hline 4 & 258.045 & 298.895 & 192.780 & 130.753 \\
\hline 5 & 369.357 & 339.679 & 295.031 & 268.521 \\
\hline 6 & 738.835 & 698.053 & 564.274 & 428.732 \\
\hline 7 & 1008.037 & 926.284 & 802.224 & 782.036 \\
\hline 8 & 1296.378 & 1139.374 & 1070.709 & 948.032 \\
\hline 9 & 1107.905 & 915.276 & 883.378 & 775.235 \\
\hline 10 & 520.703 & 448.053 & 367.048 & 312.753 \\
\hline 11 & 173.335 & 126.582 & 98.428 & 90.028 \\
\hline
\end{tabular}


Table.3 Effect of Temperature on Enterobacter spp for hydrolysis of feedstocks

\begin{tabular}{|c|r|r|r|r|}
\hline Temperature ${ }^{\circ} \mathrm{C}$ & $\begin{array}{l}\text { Beech } \\
\text { wood }\end{array}$ & $\begin{array}{l}\text { Hard } \\
\text { wood }\end{array}$ & Bagasse & $\begin{array}{l}\text { Wheat } \\
\text { Straw }\end{array}$ \\
\hline & \multicolumn{2}{|c|}{ Pentose sugar concentration in $\mu \mathrm{g} / \mathrm{mL}$} \\
\hline 20 & 32.5 & 29.7 & 22.4 & 19.0 \\
\hline 22 & 57.9 & 41.6 & 37.3 & 28.2 \\
\hline 24 & 98.1 & 74.9 & 52.8 & 40.0 \\
\hline 26 & 197.8 & 170.0 & 120.7 & 97.1 \\
\hline 28 & 286.4 & 209.1 & 197.6 & 143.8 \\
\hline 29 & 529.0 & 411.7 & 337.4 & 295.1 \\
\hline 30 & 735.5 & 700.4 & 563.0 & 522.4 \\
\hline 31 & 1007.8 & 828.3 & 801.5 & 783.2 \\
\hline 32 & 1298.4 & 1130.1 & 1082.0 & 950.4 \\
\hline 33 & 1110.8 & 916.2 & 883.1 & 773.1 \\
\hline 34 & 769.8 & 692.2 & 597.1 & 439.8 \\
\hline 35 & 521.4 & 448.5 & 368.3 & 298.4 \\
\hline 36 & 306.9 & 229.0 & 199.0 & 145.3 \\
\hline 37 & 173.2 & 125.5 & 103.3 & 90.1 \\
\hline 38 & 102.2 & 86.4 & 55.0 & 32.0 \\
\hline
\end{tabular}

Table.4 Effect of $\mathrm{pH}$ on Enterobacter spp for hydrolysis of feedstocks

\begin{tabular}{|c|r|r|r|r|}
\hline \multicolumn{1}{|l|}{$\mathrm{pH}$} & \multicolumn{1}{l|}{$\begin{array}{l}\text { Beech } \\
\text { wood }\end{array}$} & \multicolumn{1}{l|}{$\begin{array}{l}\text { Hard } \\
\text { wood }\end{array}$} & Bagasse & Wheat Straw \\
\hline \multicolumn{5}{|r|}{ Pentose sugar concentration in $\mu \mathrm{g} / \mathrm{mL}$} \\
\hline 2 & 0.0 & 0.0 & 0.0 & 0.0 \\
\hline 3 & 0.0 & 0.0 & 0.0 & 0.0 \\
\hline 4 & 0.0 & 0.0 & 0 & 0.0 \\
\hline 5 & 1.4 & 1.0 & 0.7 & 0.6 \\
\hline 6 & 7.8 & 6.9 & 3.5 & 1.2 \\
\hline 6.5 & 298.8 & 168.3 & 142.8 & 137.0 \\
\hline 7 & 847.4 & 598.4 & 455.9 & 309.5 \\
\hline 7.2 & 1438.5 & 990.7 & 805.1 & 710.8 \\
\hline 7.4 & 1773.7 & 1355.0 & 1009.7 & 928.3 \\
\hline 7.6 & 1604.8 & 1477.6 & 1280.3 & 1106.0 \\
\hline 7.8 & 1324.3 & 1186.0 & 926.7 & 896.3 \\
\hline 8 & 948.3 & 876.3 & 648.3 & 608.7 \\
\hline 8.5 & 506.7 & 399.1 & 305.0 & 300.0 \\
\hline 9 & 265.0 & 205.2 & 190.7 & 165.0 \\
\hline 10 & 156.9 & 122.4 & 107.2 & 98.7 \\
\hline
\end{tabular}


Fig.1 Enzyme activity ( $\mu$ mole/ml) of Enterobacter spp for different feed stocks

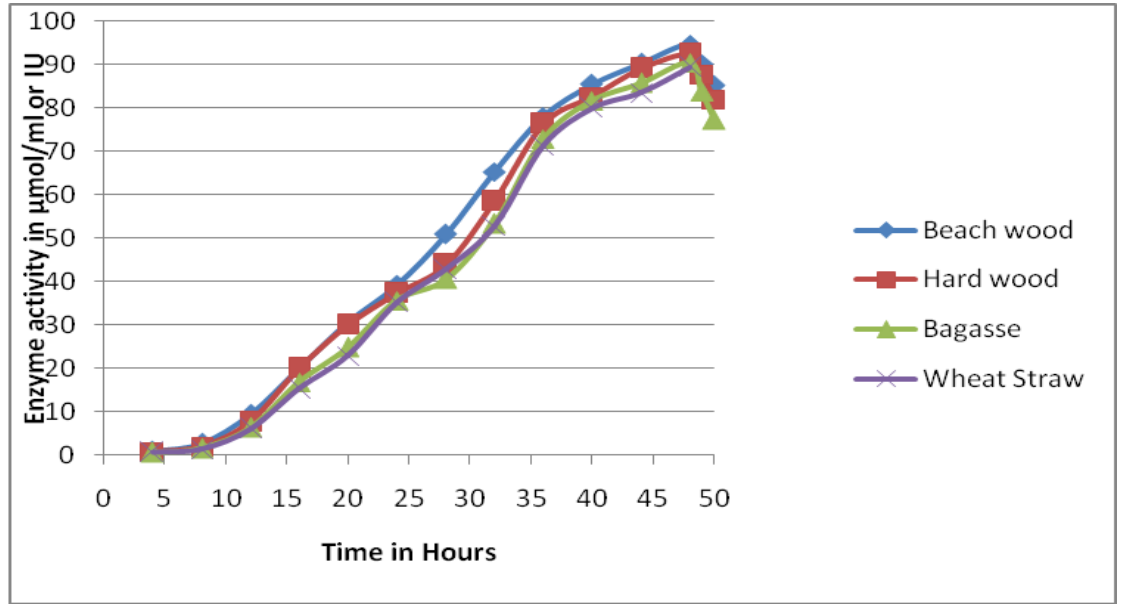

Fig.2 Effect of Hydrolysis by Enterobacter spp on substrate concentration

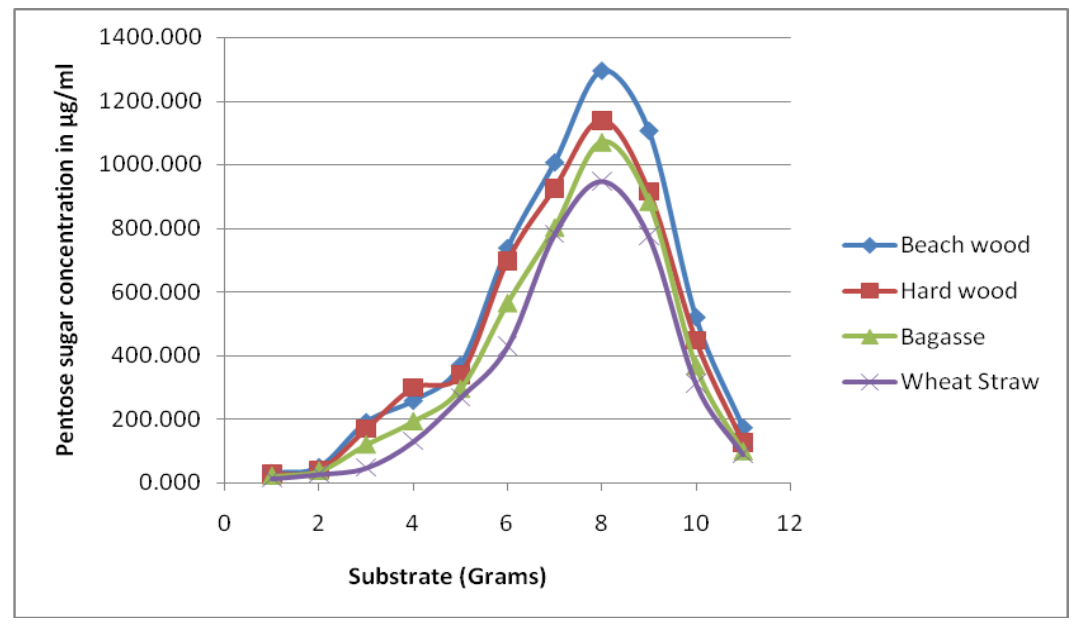

Fig.3 Effect of Temperature on Enterobacter spp for hydrolysis of feedstocks

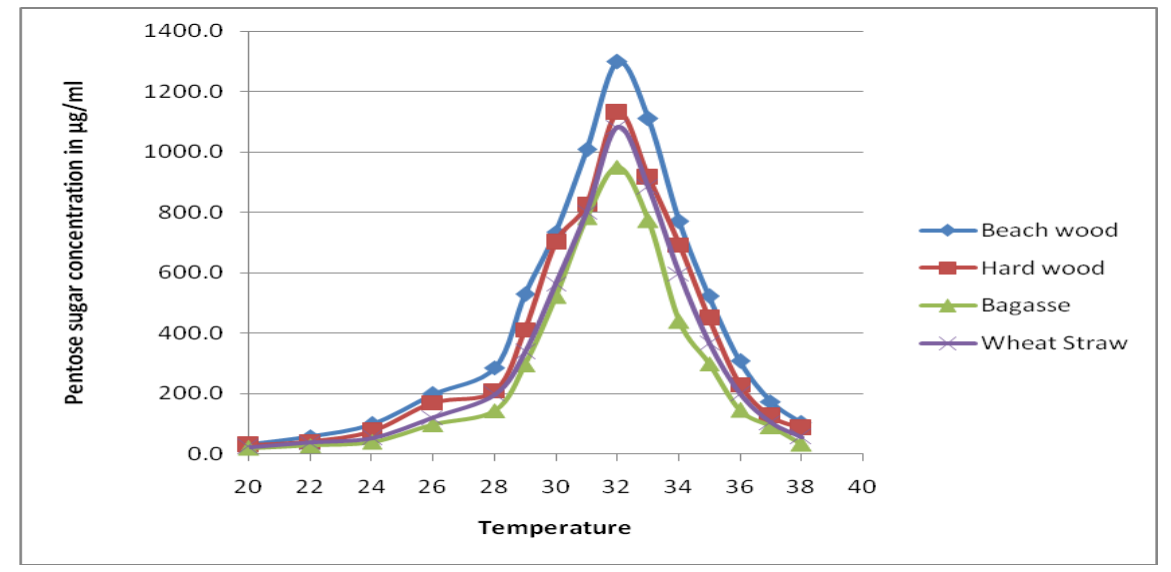


Fig.4 Effect of pH on Enterobacter spp for hydrolysis of feedstocks

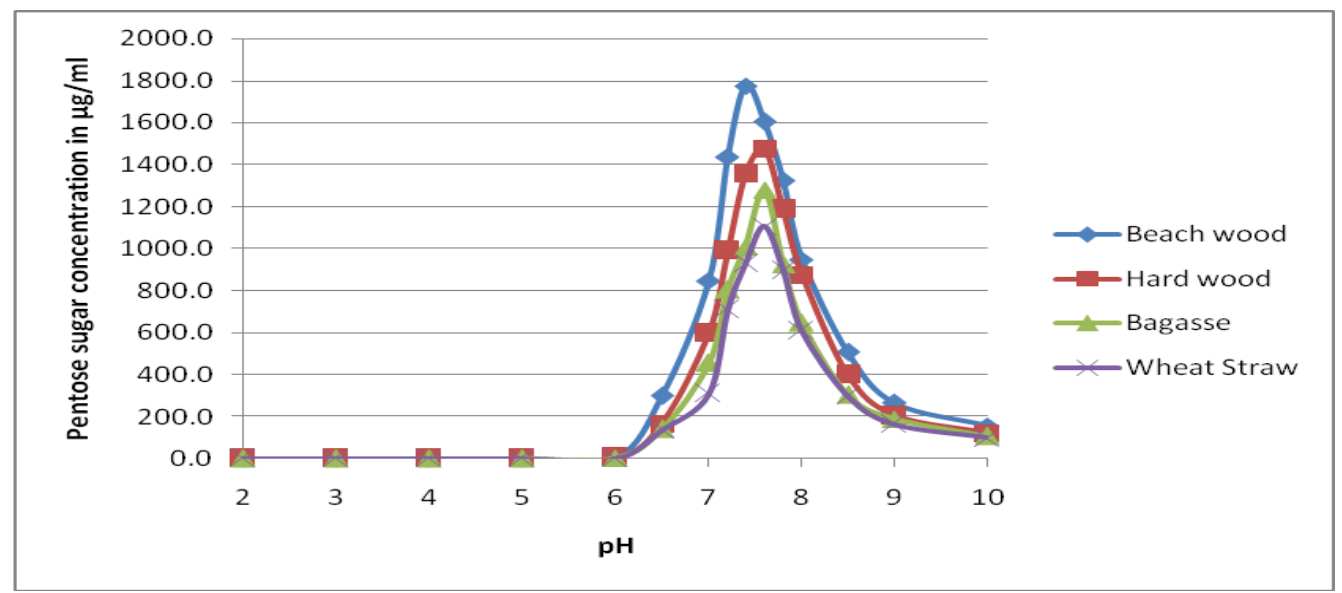

The optimum $\mathrm{pH}$ for Enterobacter species for hydrolysis of hemicellulose feedstock is 7.4. At this $\mathrm{pH}$ highest amount of sugar was released by the enzymatic activity.

\section{Ethanol production}

\section{Fermentation}

The hydrolyzed products are subjected to fermentation for the production of ethanol. E. coli strain was inoculated into the culture filtrate and allowed for fermentation for $36 \mathrm{~h}$ (Templeton, 2008).

After fermentation, it was filtered and subjected to distillation for ethanol at $80^{\circ} \mathrm{C}$ (Ghose, 1987, Milne 1992).

\section{Ethanol estimation by high pressure liquid chromatography}

The injected volume was $1 \mu \mathrm{l}$ and the retention time was $25 \mathrm{~min}$. Identification and quantification were based on direct comparison of the high performance liquid chromatogram (Waters Columns SH 1821 \& SH 1811) response to ethanol standards.

Ethanol yield was $2.3 \% \mathrm{v} / \mathrm{v}$ for beech wood, $2.1 \% \mathrm{v} / \mathrm{v}$ for hard wood, $1.92 \% \mathrm{v} / \mathrm{v}$ for bagasse\&1.7\% v/v for wheat straw was obtained.

In conclusion, the aim of this study was to gain a deeper understanding of how to process pre-treated hemicelluloses to get commercial end products. The results of the work have contributed to expanding the body of knowledge within this increasingly important field. The optimization experiments have shown that the organism isolated is an efficient hemi-cellulolytic hydrolyser. The organism effectively hydrolyzed hemicellulose to pentose sugars and this sugar was converted to bio-ethanol

\section{Acknowledgement}

The authors would like to thank the TEQIPII, BMS College of Engineering for providing the financial assistance to procure XBridge BEH Amide Column and $\mathrm{M} / \mathrm{s}$. Shilpa Medicare Limited, Raichur for permission to use the LCMS facility for sample analysis.

\section{References}

Arundel, A., Sawaya, D. 2009. Thebioeconomy to 2030: Designing a policy agenda.

Biely, P. 1985. Xylanolytic enzymes. In Whitaker, J.R.-Voragen, A.G.J.- 
Wong, D.W.S. Handbook of Food Enzymology. New York: Marcel Dekker, Inc., p. 879-915.

Börjesson, P. 2009. Good or bad bioethanol from a greenhouse gas perspectivewhat determines this? Appl. Energy, 86(5): 589-594.

Brown, C.M. 1985. Isolation methods for Microorganisms, P.(21-35) In, comprehensive Biotechnology ed. In chief-Murray Scientific fundamentals. Howard Dalton. Publ. Pergam press, Oxford.

Cai, Y.J., J.A. Buswell and Chang, S.T. 1994. Cellulases and himicellulases of Volvariella volvacea and the effect of tween 80 on enzyme production. Mycol. Res., 98: 1019-1024.

Ghose, T.K. 1987. Measurement of Cellulase Activities. Pure \& Appl. Chem., 59: 257-268.

Goldemberg, J. 2006. The ethanol program in Brazil. Environ. Res. Lett., 1(1): 014008

IEA. 2009. Transport, Energy and CO2: Moving Towards Sustainability. OECD Publishing.

Jørgensen, H., Erriksson T, Börjesson J, et al. 2003. Purification and characterisation of five cellulases and one xylanases from Penicillium brasilianum IBT 20888. Enzyme. Microb. Technol., 32: 851-861.

Milne, T.A., Chum, H.L., Agblevor, F.A., Johnson, D.K. 1992. Standardized analytical methods' biomass \& energy. Proceedings of International Energy Agency Bioenergy agreement seminar', 2-3 April 1992, Edinburgh, UK, Vol.2, 341-366.

Sluiter, Hames, B., Ruiz, C., Scarlata, J. 2008. Determination of structural carbohydrates and lignin in biomass, Laboratory analytical procedures. National Renewable Energy Laboratory.

Surender, V.J., Sindhu, R., Binod, P., Janu, K.U. 2010. Lignocellulosic ethanol in India: Prospects, challenges and feedstock availability. Biores. Technol., 101: 4826- 4833.

Templeton, Hames, B., Ruiz, C., Scarlata, J. 2008. Determination of Extractives in biomass, Laboratory analytical procedures. National Renewable Energy Laboratory.

\section{How to cite this article:}

Puttaswamy, C.T., L. Udaya Simha, S. Manjappa and Vinod Kumar, C.S. 2016. Hydrolysis of Hemicellulosic Feed Stocks by Enterobacter Species in the Production of Bio-Ethanol. Int.J.Curr.Microbiol.App.Sci. 5(7): 716-724. doi: http://dx.doi.org/10.20546/ijcmas.2016.507.082 